E.V. Isaeva, D.S. Isaev

\title{
Anaesthetic and postanaesthetic effect of isoflurane on the multiple-unit activity of the immature rat hippocampus
}

\begin{abstract}
We investigated anesthetic and postanaesthetic effect of isoflurane on the multi-unit activity (MUA) in the CA3 region of immature rat hippocampus. MUA amplitude did not significantly change during application of isoflurane. On the other hand MUA frequency significantly decreased during the anesthesia. After isoflurane discontinuation two phases of MUA frequency recovery were observed: initial rapid increase followed by a slower recovery to the control level. Comparison of recovering period of the receptor mediated systems and spontaneous field activity from isoflurane anesthesia is discussed.

Key words: isoflurane, multiple-unit activity, rat, hippocampus.
\end{abstract}

\section{INTRODUCTION}

Isoflurane is a volatile anesthetic which induces and maintains general anesthesia by depression of the central nervous system. Isoflurane is widely used in clinical practice in children and adult patients; however the precise mechanism of the action of this anesthetic is not clear. In spite of that fact that general anesthetics result in loss of consciousness, structures such the medial septum and hippocampus remain active during the general anesthesia. It has been proposed that these forebrain structures participate in maintaining awareness and movements during general anesthesia [11]. In our previous report we showed that isoflurane effectively stop seizures induced by intrahippocampal injection of high potassium/low magnesium contained artificial cerebrospinal fluid (ACSF) in immature rats [6]. The goal of the present study is to characterize spontaneous field activity in the rat hippocampus during isoflurane anaesthesia and in postanaesthetic transition period.

\section{METHODS}

Acute hippocampal slices were prepared from (C) E.V. Isaeva, D.S. Isaev
Sprague-Dawley rats aged postnatal (P) days 8-15 as previously described [8]. Briefly, hippocampal slices $(500 \mathrm{~mm})$ were cut using a Leica VT $1000 \mathrm{~S}$ vibroslicer (Leica Microsystems, Nussloch GmbH, Germany). For recordings, slices were transferred to a chamber mounted on an Olympus BX51WI (Japan) microscope with an X40 water-immersion objective and infrared, differential interference contrast optics. The slices were continuously superfused with oxygenated $\left(95 \% \mathrm{O}_{2}-\right.$ $5 \% \mathrm{CO}_{2}$ ) ACSF consisted of the following composition: $125 \mathrm{mM} \mathrm{NaCl}, 3.5 \mathrm{mM} \mathrm{KCl}$, $2 \mathrm{mM} \mathrm{CaCl}_{2}, 1.3 \mathrm{mM} \mathrm{MgCl}, 24 \mathrm{mM} \mathrm{NaH}-$ $\mathrm{CO}_{3}, 1.25 \mathrm{mM} \mathrm{NaH} \mathrm{PO}_{4}$, and $11 \mathrm{mM}$ glucose at a rate of $2-4 \mathrm{ml} / \mathrm{min}$ at $30-32^{\circ} \mathrm{C}$. Extracellular field potential recordings were obtained from CA3 pyramidal cell layer. Field potential recordings were made using borosilicate glass capillaries filled with ACSF and twochannel AC differential amplifier (A-M Systems, Carlsborg, WA). Pipette resistance ranged from 1-3 $M \Omega$. All recordings were digitized $(10 \mathrm{kHz})$ online with an analogue-todigital converter Digidata 1322A (Axon Instruments, Union City, CA) and analyzed us- 
ing Clampfit (Axon Instruments, Foster City, USA) and Origin 7.0 (Microcal Software, Northampton, MA) software. Application of isoflurane was made using isoflurane vaporizer (Isotec 3, Ohmeda Medical System, Herts, UK). To minimize loss and binding of isoflurane, application was made using polytetrafluoroethylene tubes.

\section{RESULTS AND DISCUSSION}

In the extracellular recording, MUA reflects the action potentials from 10-100 neurons 1ocated in the vicinity of the recording electrode. Spike amplitudes ranged 50-150 $\mu \mathrm{V}$ from the noise level, suggesting that electrodes detected discharges from multiple neurons. MUA was always apparent in extracellular records from the CA3 pyramidal cell layer (Fig. 1). The average inter-event interval of detected spikes in control condition was $88.3 \pm 20.3 \mathrm{~ms}$ $(n=12)$. Following the application of $1.5 \mathrm{mini}-$ mum alveolar concentration (MAC) of isoflurane the inter-event interval of spikes greatly increased consistent with a general sedative action of the anesthetic agent (Fig. 1 and 2A). We did not find a significant difference in maximal amplitude of spikes recorded from slices in control and isoflurane exposed conditions ( $p=0.96$, Mann-Whitney test, Fig. 2B). After isoflurane discontinuation two phases of spike frequency recovery were observed: initial rapid recovery $(2 \mathrm{~min})$ followed by a slower recovery (near $50 \mathrm{~min}$ ). Only in 4 slices out of 12 the frequency of spikes reached their control level after 10-20 minutes of washout. In the rest 8 slices MUA frequency rapidly and greatly increased comparatively to the control MUA frequency. The MUA frequency was still significantly increased comparatively to control conditions thirty minutes after isoflurane washout $(\mathrm{p}<0.05$, Mann-Whitney test, Fig. 2A). The amplitude of MUA was not altered by discontinuation of isoflurane exposure.

Recording of MUA reflects the spontaneous activity of large number of neurons in the vicinity of the extracellular electrode. This activity of a neuronal network may depend on afferent signaling or being result from processes intrinsic to the network. In vitro studies suggest that many brain areas, including CA3 pyramidal cell layer, may generate discharges in the absence of external inputs (Cohen and Miles, 2000). Both intrinsic cellular properties and synaptic connections within the network could contribute to MUA activity. There is general agreement that $\mathrm{GABA}_{\mathrm{A}}$ receptors are an important target for isoflurane $[1,2,9,10]$. On the other hand, many studies show the excitatory synaptic system as a potential target of general anesthetics including isoflurane [12, 14, 17]. Also non-receptor mediated action of isoflurane was shown in neocortical and hippocampal neurons [3, 5].

In our previous report we show that application of isoflurane significantly increased the tonic conductance, decreased the amplitude and frequency, and prolonged the decay of spontaneous inhibitory postsynaptic
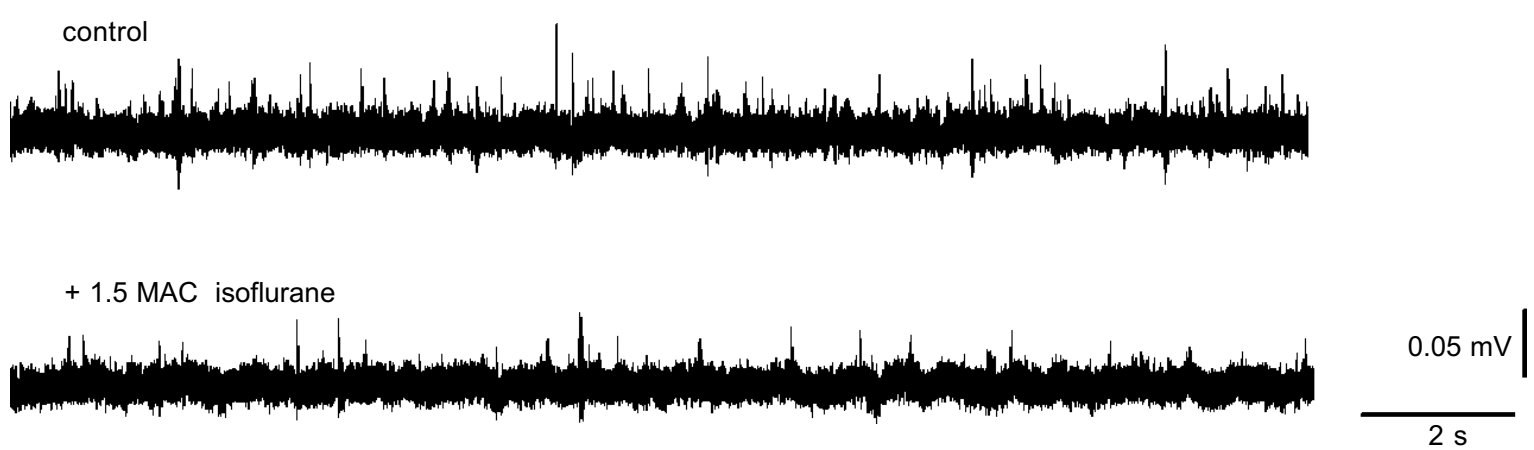

Fig. 1 Isoflurane decreases the hippocampal spontaneous firing activity. Extracellular recordings were made from hippocampal CA3 pyramidal layer of P11 rat before (upper panel) and during (lower panel) exposure to isoflurane 
currents (sIPSC) recorded from hippocampal pyramidal neurons [6]. Also isoflurane reduced the amplitude and charge transfer of nonNMDA mediated spontaneous excitatory postsynaptic currents (sEPSC). Decreasing of the MUA frequency during isoflurane anesthesia can be accounted at least in part on its effect on synaptic transmission.

Previous report demonstrates that recovering from isoflurane was different for inhibitory and excitatory neuronal activity recorded in hippocampal fraction [7]. Parameters of nonNMDA sEPSCs completely recovered to control conditions after $10 \mathrm{~min}$ of washout from isoflurane. Nishikawa and MacIver [13] using the same concentration of isoflurane as in the present study showed that fEPSPs mediated by postsynaptic NMDA receptors are
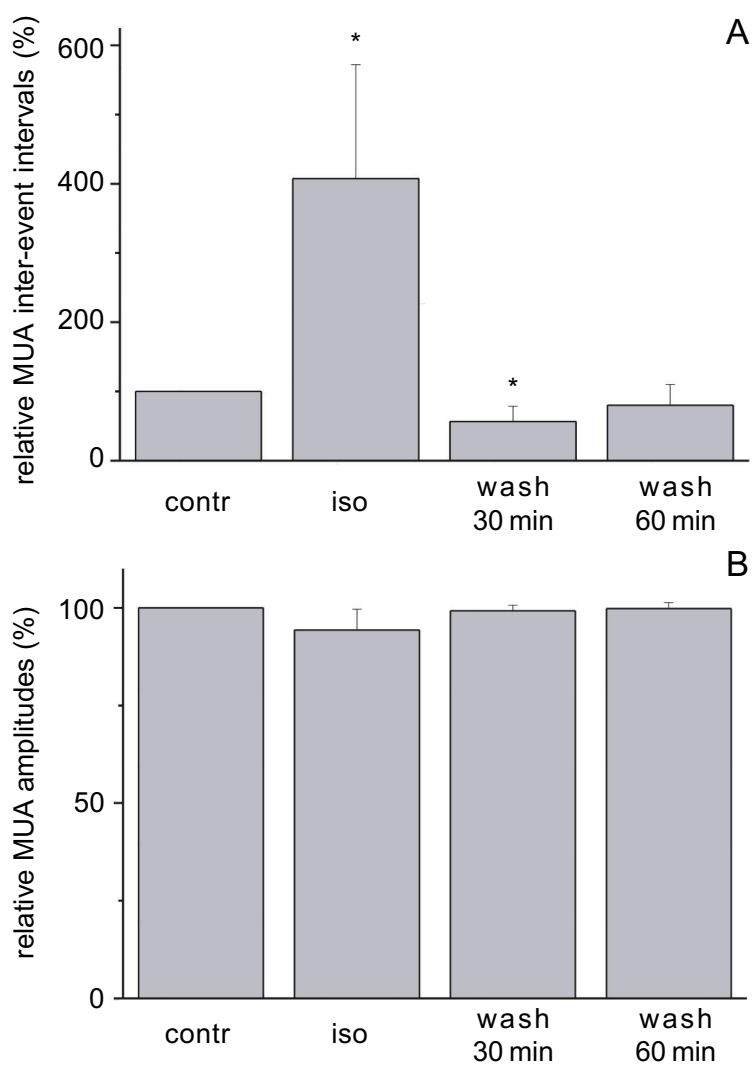

Fig. 2 Effect of isoflurane on different characteristics of MUA activity. (A, B) Summary plots show the effect of 1.5 MAC of isoflurane on inter-event interval and amplitude of MUA. All values are Means \pm SEM more sensitive to clinically relevant concentrations of isoflurane then non-NMDA receptor mediated responses, and full recovery of nonNMDA and NMDA fEPSPs occurred during 30 minutes of washout from isoflurane. We conclude that the increasing of the frequency of multi-unit activity during isoflurane washout could not depend on the recovery of the excitatory synaptic transmission.

Washout of inhibitory synaptic transmission from isoflurane anesthesia is substantially slower then the recovery of the excitatory synaptic transmission [8]. Activation of GABA mediated $\mathrm{Cl}^{-}$channels results in intracellular accumulation of chloride and depression of inhibition. We suggest that increasing $\mathrm{Cl}^{-}$intracellular concentration due to the increasing of opening time of GABA mediated $\mathrm{Cl}^{-}$channels can explain at least in part increasing of MUA frequency during washout of isoflurane. Another possible explanation of prolong recovery of MUA from anesthesia could be account for prolong recovering period of non-receptor systems from anesthesia [16].

Recovery from general anesthesia is complex process and can take from minutes to hours depending on anesthetic agent. From clinical studies emergence time from discontinuation of isoflurane anesthesia to command response, and orientation were quite fast ( $12 \pm 0.5 \mathrm{~min})$, however complete recovery from isoflurane anesthesia takes hours [15]. The present study adds further insight into understanding cellular mechanisms of recovery from inhalation anesthetic agents.

Supported by NATO Science Program.

\section{О.В. Ісаєва, Д.С. Ісаєв}

\section{АНЕСТЕЗІЙНИЙ ТА ПОСТАНЕСТЕЗІЙНИЙ ЕФЕКТ ІЗОФЛЮРАНА НА ЕЛЕКТРИЧНУ АКТИВНІСТЬ НЕЙРОНІВ У ГІПОКАМПІ МОЛОДИХ ЩУРІВ}

Ми досліджували анестезійний та постанестезійний вплив ізофлюрану на електричну активність нейронів (ЕАН) у ділянці гіпокампа САЗ молодих щурів. Ізофлюран істотно не змінював амплітуду ЕАН, з іншого боку, частота ЕАН 
значно знизилася. Після припинення аплікації ізофлюрану спостерігали дві фази відновлення частоти ЕАН: по-перше, швидке зростання, а потім повільне зниження до контрольного рівня. Порівняння відновлення рецепторної системи і активності нервової мережі після дії ізофлюрана обговорюється.

Ключові слова: ізофлюран, електрична активність нейронів, гіпокамп, щур.

\section{Е.В. Исаева, Д.С. Исаев}

\section{АНЕСТЕТИЧЕСКИЙИ ПОСТ-АНЕСТЕТИЧЕСКИЙ ЕФФЕКТ ИЗОФЛЮРАНА НА ЭЛЕКТРИЧЕСКУЮ АКТИВНОСТЬ НЕЙРОНОВ В ГИППОКАМПЕ МОЛОДИХ КРЫС}

Мы исследовали анестетический и постанестетический эффект изофлюрана на электрическую активность нейронов (ЭАН) в области гиппокампа САЗ молодых крыс. Изофлюран существенно не изменял амплитуду ЭАН, в то же время частота ЭАН значительно снизилась. После прекращения аппликации изофлюрана наблюдалось две фазы восстановление частоты ЭАН: быстрое увеличение вначале, с последующим медленным снижением до контрольного уровня. Сравнение действия изофлюрана на синаптическую активность и на общую активность нервной сети обсуждается.

Ключевые слова: изофлюран, электрическая активность нейронов, гиппокамп, крыс.

\section{REFERENCES}

1. Antkowiak B. Different actions of general anesthetics on the firing patterns of neocortical neurons mediated by the GABA(A) receptor // Anesthesiology. - 1999. 91. - P.500-511.

2. Banks M.I., Pearce R.A. Dual actions of volatile anesthetics on GABA(A) IPSCs: dissociation of blocking and prolonging effects // Ibid. - 1999. - 90. - P.120-34.

3. Berg-Johnsen J., Langmoen I. A. Mechanisms concerned in the direct effect of isoflurane on rat hippocampal and human neocortical neurons // Brain Res. - 1990. - 507. - P. 28-34.

4. Cohen I., Miles R. Contributions of intrinsic and synaptic activities to the generation of neuronal discharges in in vitro hippocampus // J. Physiol. - 2000. - 524(2). P.485-502.

O.O. Bogomoletz Institute of Physiology National Academy of Sciences of Ukraine, Kyiv

E-mail: olena.isaeva@biph.kiev.ua
5. el-Beheiry H., Puil E. Postsynaptic depression induced by isoflurane and althesin in neocortical neurons // Exp. Brain Res.- 1989. - 75. - P.361-368.

6. Isaeva E. V. Effects of isoflurane on hippocampal seizures at immature rats in vivo // Фізіол. журн. - 2008. 54(5). - P.40-45.

7. Isaeva E., Isaev D., Holmes G. L. Anesthetic and postanesthetic effects of isoflurane on neuronal activity in the rat hippocampus // Neurophysiology. - 2007. 39. - P.325-326.

8. Isaeva E., Isaev D., Khazipov R., Holmes G.L. Selective impairment of GABAergic synaptic transmission in the flurothyl model of neonatal seizures // Eur. J. Neurosci. - 2006. - 23(6). - P.1559-1566.

9. Jones M.V., Brooks P.A., Harrison N.L. Enhancement of gamma-aminobutyric acid-activated $\mathrm{Cl}$ - currents in cultured rat hippocampal neurones by three volatile anaesthetics // J. Physiol. - 1992. - 449. - P.279-293.

10. Jones M.V., Harrison N.L. Effect of volatile anesthetics on the kinetics of inhibitory postsynaptic currents in cultured rat hippocampal neurons // J. Neurophysiol. 1993. - 70(4). - P.1339-1349.

11. Ma J., Shen B., Stewart L.S. The septohippocampal system participates in general anesthesia // J. Neurosci. 2002. - 22. - P.1-6.

12. Maclver M.B., Mikulec A.A., Amagasu S.M., Monroe F.A. Volatile anesthetics depress glutamate transmission via presynaptic actions // Anesthesiology. - 1996. 85. - P.823-34.

13. Nishikawa K., MacIver M.B. Excitatory synaptic transmission mediated by NMDA receptors is more sensitive to isoflurane than are non-NMDA receptor-mediated responses // Ibid. - 2000. - 92(1). - P.228-236.

14. Ouanounou A., Carlen P.L., El-Beheiry H. Enhanced isoflurane suppression of excitatory synaptic transmission in the aged rat hippocampus // Brit. J. Pharmacol. - 1998. - 124. -P.1075-1082.

15. Philip B.K., Kallar S.K., Bogetz M.S. A multicenter comparison of maintenance and recovery with sevoflurane or isoflurane for adult ambulatory anesthesia. The Sevoflurane Multicenter Ambulatory Group // Anesth. Analg. - 1996. - 83(2). - P.314-319.

16. Ries C.R., Puil E. Mechanism of anesthesia revealed by shunting actions of isoflurane on thalamocortical neurons // J. Neurophysiol. - 1999. - 81(4). - P.1795-1801.

17. Wakasugi M., Hirota K., Roth S.H., Ito Y. The effects of general anesthetics on excitatory and inhibitory synaptic transmission in area CA1 of the rat hippocampus in vitro // Anesth. Analg. - 1999. - 88. - P. 676-680. 